\title{
Sustainability and Market Orientation in the Brazilian
} Beef Chain

\author{
Miguelangelo Gianezini ${ }^{1,2}$, Júlio Otávio Jardim Barcellos ${ }^{1}$, Clandio Favarini Ruviaro ${ }^{1,3}$, Tamara Esteves de \\ Oliveira $^{1}$ and Homero Dewes ${ }^{1}$ \\ 1. Center for Study and Research in Agribusiness (CEPAN), Universidade Federal do Rio Grande do Sul, Porto Alegre 33086-586, \\ Brazil
}

2. Department of Socioeconomic Development (PPGDS), Universidade do Extremo Sul Catarinense (UNESC), Criciúma 88806-000, Brazil

3. Department of Agribusiness (FACE), Universidade Federal da grande Dourados (UFGD), Dourados 79804-970, Brazil

Received: March 17, 2014 / Published: April 20, 2014.

\begin{abstract}
The demand for natural resources, energy and food facing the contemporary perception of sustainability is imposing challenges to the productive sectors in accordance with market guidelines. In this context, the Brazilian agribusiness seeks to maintain external competitiveness and to satisfy growing domestic demands. In beef production, this competitiveness pervades traceability, food safety and sustainability. This article aims to identify the sustainability state of the art in agribusiness and characterize it within the Brazilian beef chain. Descriptive methodology, combining a literature review and a documentary data survey were adopted. An outline of the dimensions of agribusiness sustainability, drawn from benchmark practices, indicates that environmental, social and technological demands have become part of the industry's agenda. The data for beef cattle point to a growth in production but demonstrate that expansion has occurred in areas of environmental tension, which creates a demand for sustainability in the beef chain. A table of guidelines for sustainability demonstrates that although perceptions are not yet harmonized among the links in the whole beef chain, many of the technological guidelines for sustainable production may increase the producer's economic efficiency. In the Brazilian case, the increment of initiatives and dissemination of sustainable practices among the beef chain is desirable to provide a coordinated response of production, processing and distribution organizations facing market opportunities for sustainable livestock.
\end{abstract}

Key words: Agribusiness, livestock, process, sustainable production, demand chains.

\section{Introduction}

The era of the knowledge society can also be regarded as the era of the consumer society, due to the growing demand for natural resources, energy and food. In this contemporary setting, there is a perception of multidimensional sustainability [1-5] that influences the opinion and habits of society. This perception represents a challenge for various sectors, which analyze and implement adjustments in their

Corresponding author: Miguelangelo Gianezini, Ph.D., research fields: sustainability, strategy, management and technology. E-mail: miguelgianezini@hotmail.com. supply chains in accordance with the guidelines of the emerging markets.

The concept of market orientation (MO) and its influence on organizational performance have been the focus of several studies demonstrating that organizations aligned with their clients and with market demands are more suitable to offer products, services and solutions of superior performance [6-8]. The term market-oriented can be interpreted in many ways. For the sector of research and development, this term may mean the product specifications and technical characteristics; for manufacturing, it may 
mean durability and safety; for marketing, it may mean consumer desires; and for business planning, it may mean "having the product in the appropriate market niche” [9].

In the evolution of the concept of MO, two approaches have been adopted [10]. The first is a cultural perspective on organizational norms and values that encourage behaviors consistent with the MO [6]. The MO is shown as a concept created from three elements: customer orientation, with the enterprises being directed toward the needs of customers; competitor orientation, which analyzes the opposing strategy and market movements; and inter-functional coordination, which introduces cooperation among employees.

The second approach identifies three primary components of the concept: the generation of market information on current and future customer needs and the skills to meet them; the integration and dissemination of such information among departments and individuals within the company; and the design and implementation of a coordinated response across the organization to market opportunities [7, 11, 12]. This behavioral perspective focuses on organizational and human activities related to creating and propagating market intelligence, as well as reacting to it [13].

Both approaches to MO are complementary in explaining companies' behavior [14]. Therefore, the second approach leads to the idea of a demand chain (DC) as a complex network of enterprise entities that not only follows demand in a reactive or oriented perspective but is also capable of leading it [15].

The underlying theories that contributed to the formation of supply chain management (SCM) and their evolution into demand chain management (DCM) are presented in Fig. 1.

These theories have been sources for SCM and also fundamentally influence the concept of DCM. In short, as SCM is derived from logistics, DCM is an extension of SCM but with a strong emphasis on demand management due to the incorporation of the MO perspective [15].

Noting the key features of DC, it is clear that its focus is on meeting the demand within certain markets. The demand goal in DC is to generate revenue through consumer understanding and demand management, and the supply goal is to align the business

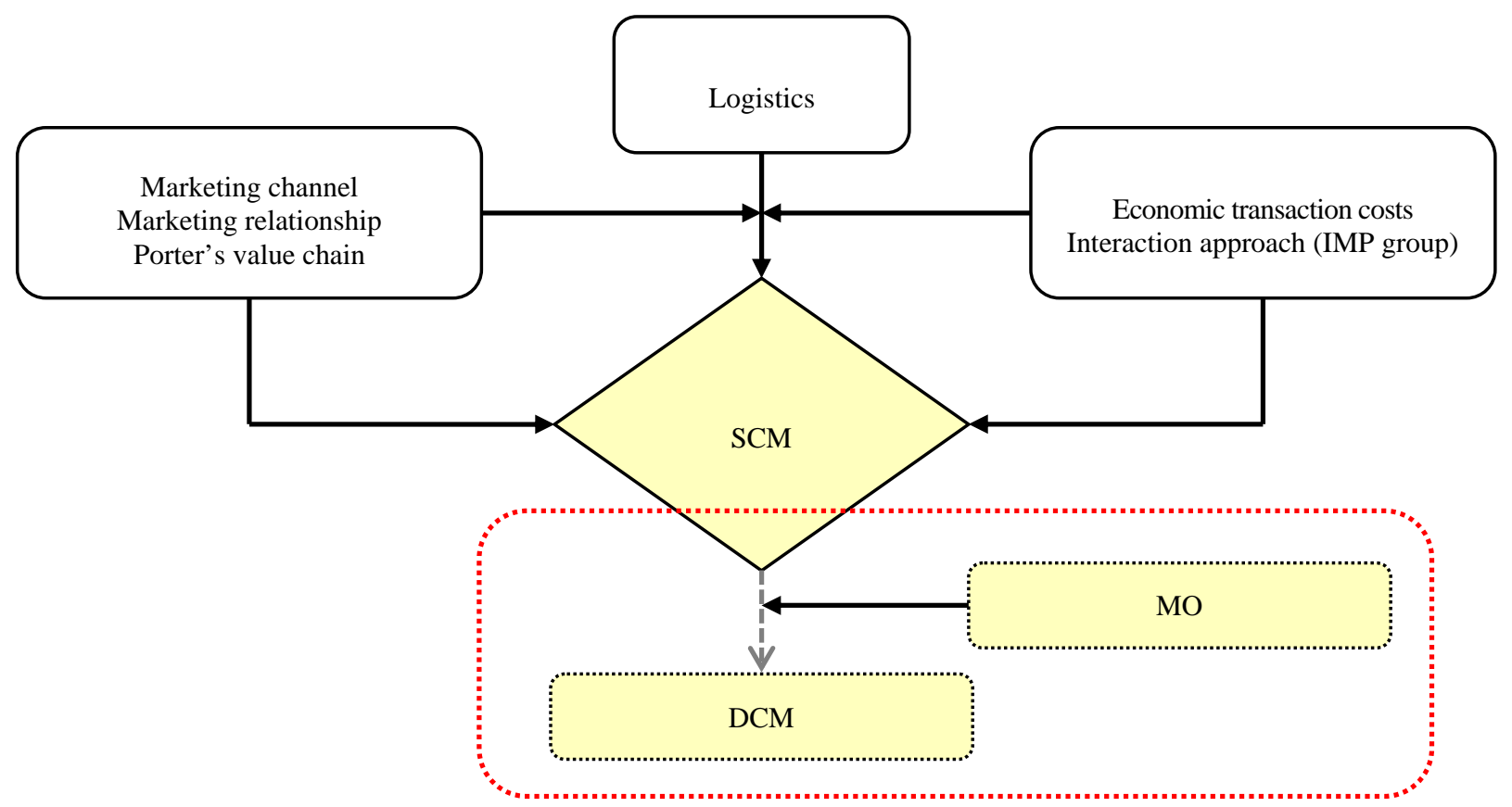

Fig. 1 Sources of the concept of SCM and their evolution into DCM.

Source: Authors' adaptation based on Ref. [15]. 
processes within and among enterprises, thereby increasing their effectiveness. The DC is also characterized for aggregating greater value, being short and having a flow of information with the consumer permeating all its stages [16-18].

Based on this theoretical development, it is observed that DCM aims to manage and coordinate an entire chain (in reverse), from the final customer (downstream) and working backward to suppliers of raw materials (upstream).

In the context of agribusiness, this possibility represents a challenge because its importance in the economic development process of many countries means it is necessary to ensure harmony between the expansion of farming and issues involving environmental preservation.

As an emerging economy, Brazil has built an efficient and competitive production system in agribusiness [19] but still seeks an economic and socio-environmental balance to maintain its competitiveness within a global production system.

In this context, an imposing movement deserves attention, involving the broader concept of sustainability. This concept is the phenomenon of transitioning from a focus on the environment alone to a broader focus - complex and subjective - of which the environment is part [20]. For many consumers, it is not sufficient for the product to be "green", and its production process must be sustainable [21].

This perception of sustainability in agribusiness has marked recent discussions of animal production systems, focusing on the cattle industry's influence on the environment [22]. This is especially the case in Brazil, where the relevance of studies and analysis of beef production is supported by the magnitude of its commercial bovine herd, repeatedly considered the largest in the world [23-25]. However, attaining this position has attracted the world's attention, and the maintenance of such a leadership implies challenges that pervade competitiveness, traceability, food security, innovation and sustainability [26, 27].
Therefore, the characterization of sustainability in Brazilian beef production becomes relevant not only because there are few publications that support scientific understanding and managerial decisions but also because it may signify an important trend in a market in which the productive and commercial orientations are not fully captured by the various chain agents.

The objective of this study is to review the current conceptual state of agribusiness sustainability in the framework of MO and to describe the condition of sustainable livestock breeding in Brazil, focusing on the beef supply chain.

\section{Materials and Methods}

This report describes a descriptive study that combines bibliographical and documentary research based on secondary information from 2001 to 2012 . Research procedures, data collection techniques and result analyses consisted of:

(1) Literature review of $\mathrm{MO}$ and demand chains theories and concepts of agriculture and livestock sustainability. The search for references was carried out using Web of Science, Scopus and other databases;

(2) Surveying documents-from directories, reports and websites - of beef market data in Brazil and information from the agents promoting sustainable livestock production within the country. The documents were searched in secondary databases from Brazilian institutions and enterprises, such as the livestock directory (ANUALPEC), the agricultural research agency (EMPBRAPA) linked to the Ministry of Agriculture, Livestock and Food Supply (MAPA), the decennial farm census data obtained from the Brazilian Institute of Geography and Statistics (IBGE), and sustainable initiatives promoted by Brazilian retailers companies.

Secondary quantitative and qualitative data were used to describe the Brazilian scenario, elaborate an illustrative scheme for agricultural sustainability and build a characterization table of sustainable practices 
in the Brazilian beef chain that was analyzed according to the concepts of MO and DCM (Fig. 1).

\section{Results and Discussion}

\subsection{Sustainability, Sustainable Production and} Agribusiness

The subject of sustainability became popular with the publication of “Our Common Future: The World Commission on Environment and Development” [28], as elaborated by the World Commission on Environment and Development. This report presents the first definition of sustainability, understood as "the ability to meet the needs of the present generations without compromising the ability of future generations to meet their own”.

In the 1990s, the sustainability of agricultural systems and practices were clearly integrated into this discussion in different dimensions. The environmental dimension consists of sustainable development as improvement in humanity's life quality, respecting the supporting capacity of ecosystems. The economic dimension contains the sustainable economy as a product of sustainable development maintaining the production basis of natural resources. The social dimension contains the sustainable society, as one which would continue to develop itself by adapting and expanding knowledge, organization, technical efficiency and wisdom [2, 29].

During this period, we highlight the Food, Agriculture, Conservation and Trade Act, in which the United States government defines sustainable agriculture as “an integrated system of plant and animal production practices having a site-specific application that will, over the long term, satisfy human food and fiber needs, enhance environmental quality and the natural resource base upon which the agricultural economy depends, make the most efficient use of nonrenewable resources and on-farm resources and integrate, where appropriate, natural biological cycles and controls, sustain the economic viability of farm operations, and enhance the quality of life for farmers and society as a whole" [30].

In the first decade of the 21st century, private conglomerates entering this scenario and the previous concepts gained complementarities on the concept of the Sustainable Agriculture Initiative Platform: "Sustainable agriculture is a productive, competitive and efficient way to produce safe agricultural products, while at the same time protecting and improving the natural environment and social/economic conditions of local communities” [4].

The result of this evolution is also accompanied by contemporary studies, ranging from proposals for structuring a specific scientific field to study sustainability [5] to recommendations for innovative policy developments in sustainability [31] and approaches to sustainability applied to different areas of knowledge.

Among these approaches, there are readings, interpretations and derivations, as well as suggestions for new types of sustainability to complement the triple bottom line-economic, social and environmental-with a fourth type of sustainability such as institutional sustainability [32], cultural sustainability [33], territorial and political sustainability [34] or financial sustainability [35].

There is also a recent trend used in this study that became important in the recent discussions of sustainability. That is technological sustainability, which means the equilibrium or adequacy of technology for developing a certain rural or agro-industrial activity. Further, this technological balance should not only be associated with the size of the property or company but also with the geographic location, competition, industry, the consumer market and other factors.

The contemporary understanding of sustainability, when applied to agribusiness, demanded the elaboration of a scheme from the assemblage of various sources (Fig. 2), representing the evolution of the concept, as well as the actions and elements that the involved parties must observe. 


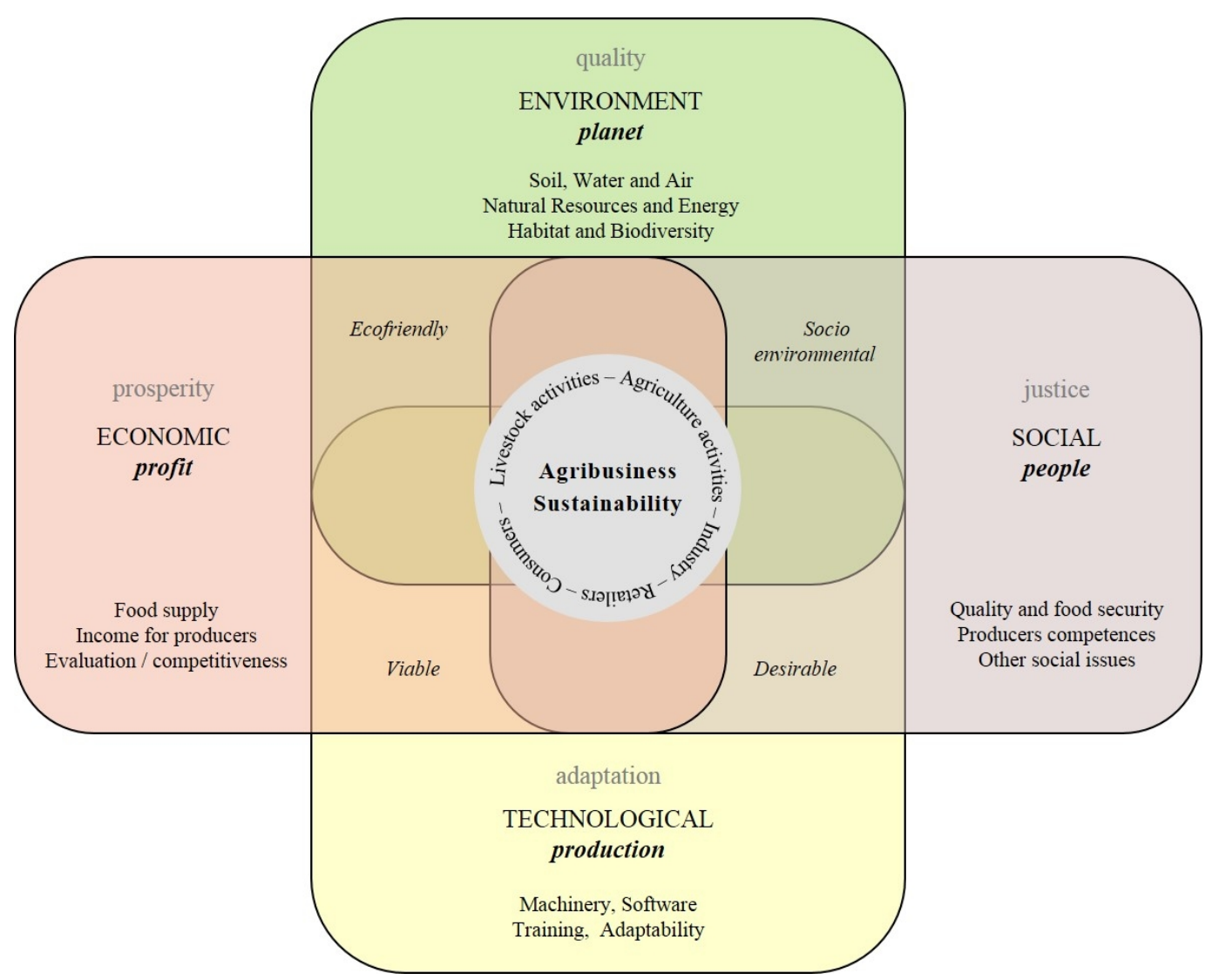

Fig. 2 Scheme of dimensions, actions and elements of sustainability in agribusiness.

Source: Elaborated by authors.

The analysis of the results that is summarized in the scheme refers to the search for sustainable production-understood as the creation and processing of products using clean processes and systems that conserve energy and natural resources, are economically viable and are safe and healthy for workers, communities and consumers [36]. The result is a sustainable product that is designed with respect to its relationship with the environment [37], given its direct impact and connections among social, economic and environmental systems.

Therefore, it is observed that "clean" agricultural technologies, classified as sustainable in the literature, can provide both environmental conservation and more equitable economic systems [38, 39].

The development of these new technologies will meet worldwide interest in the sustainability of agricultural systems. This interest has increased due to factors as environmental problems, constant pressure on farm incomes, concerns about animal welfare and occurrence of diseases that impact the reputation of Brazilian livestock.

In this context, in which sustainability appears as a key element in agribusiness' market orientation, strengthening socially and environmentally correct productive (and economically viable) options also becomes a concern of the agents in the Brazilian beef supply chain that-initially by pressure from external markets but also by the potential of the internal market-have adhered to such initiatives as sustainable livestock breeding, which is discussed next.

\subsection{Livestock and Sustainable Breeding in Brazil}

The Brazilian beef cattle industry previously has been characterized by its resistance to technological 
innovation and archaic management [40]. The sector's stagnation until the mid-nineties was the result of the extensive exploration model based on the great offer of land. The cattle herd served as a capital reserve at the time of inflation and as an instrument for consolidating the country's agricultural frontier [41].

During the first decade of this century, this picture changed. With political and economic stability, Brazil was able to develop its productive potential and consolidated its position as a world food supplier. Livestock has become a protagonist of agribusiness expansion in the country, while professionalization of the activities was initiated [42] inside (i.e., management, nutrition, health, genetics and management) and outside the farm (i.e., slaughter, processing and distribution) [41].

The Brazilian bovine herd had as many as 173 million heads in 2009, 79\% for meat and 21\% for milk production within an area of 175 million ha [25]. The country is one of the world's two major beef producers, with 7.6 million tons carcass weight equivalence (CWE) per year, and is the leading beef exporter, with 1.6 million tons CWE per year commercialized [24, 25].
These numbers represent the economic result of the growth in cattle breeding-although it is not fully consolidated, and its environmental consequences are not yet fully known—associated with the expansion of the Brazilian agricultural frontier.

In the last 15 years, it was observed that the expansion of this frontier, especially in the Center-West and North regions, had resulted in approximately $40 \%$ growth of the cattle herd (Fig. 3).

However, it must be highlighted that this expansion occurred in legally and environmentally complex areas, known as the Brazilian Legal Amazon, where herd expansion was $178 \%$ [43]. This indicated the migration of consolidated breeding areas into new areas [44] and also reduced technology use and investment to produce more in the same area [45].

In this case, the negative impact on productivity appears in the "stocking rate" (0.76 animal unit $\mathrm{AU} / \mathrm{ha}$ ), which is smaller compared to other countries and below the real potential of Brazil. If this ratio was $1 \mathrm{AU} / \mathrm{ha}$, then the herd would come to 230 million heads without increasing the explored area [24, 45].

Based on these data, it is observed that the increasing professionalization of management may, at

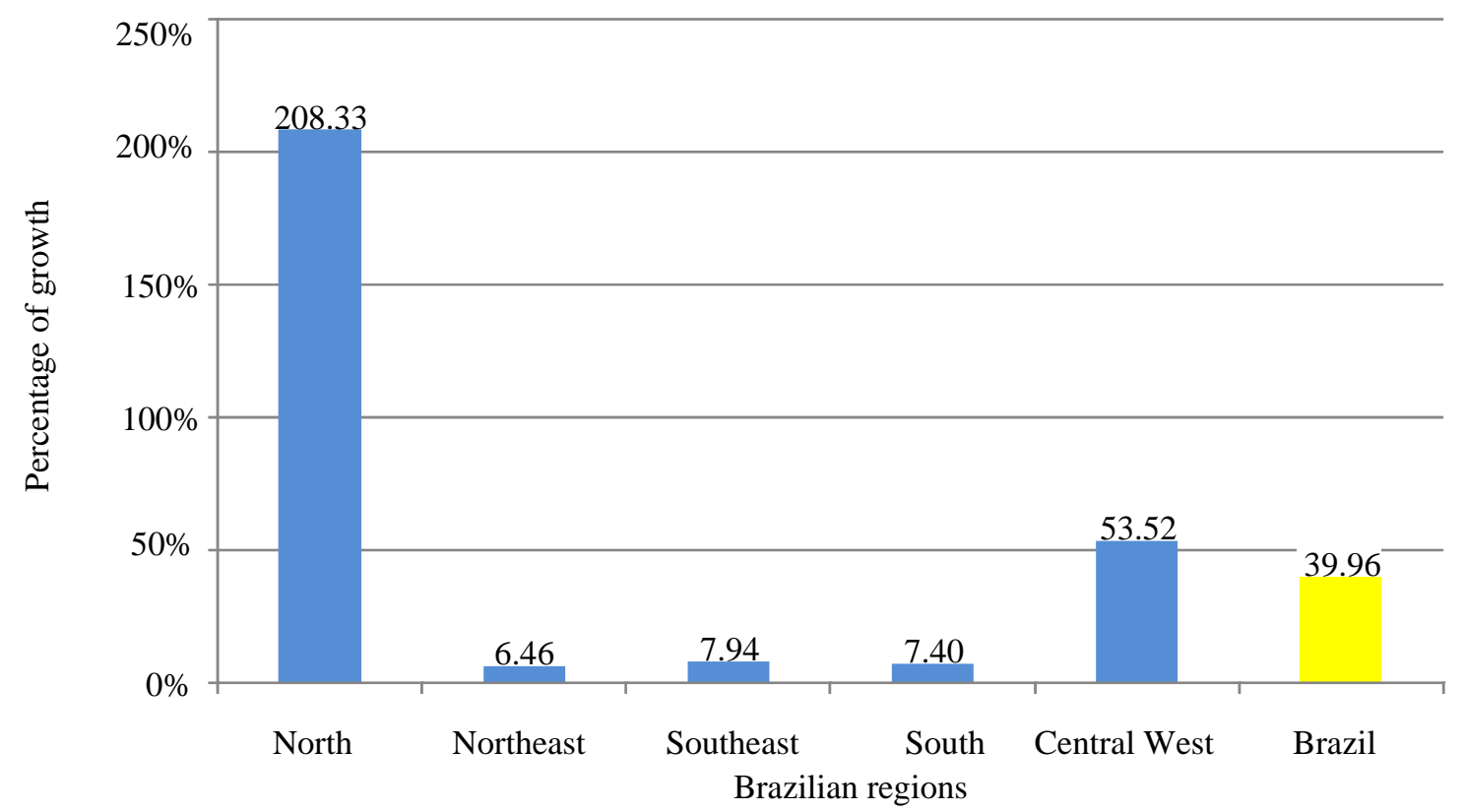

Fig. 3 Graph of the evolution of Brazilian cattle by region 1994-2009.

Source: Ref. [43]. 
first, overcome these issues. In a second stage, it becomes necessary to turn attention to other practices to raise livestock to a more productive level.

In this new level, sustainability demanded by the advance of cattle in some regions must be pursued, which generates an environmental liability, followed by internal and external pressures.

Such pressures have widened with the publication of the report Livestock's Long Shadow [46]. This document indicates that population growth has required greater use of natural resources, energy and food. Thus, the cattle industry is considered one of the main sectors responsible for greenhouse gas emissions and environmental degradation, which also involves the performance of refrigerated stores and retail chains.

However, the FAO estimated that the global demand for livestock products should experience strong growth by 2050. In addition, the critical approach of 2006 gave way to a recent review of livestock's role in this context, within the report Review of Evidence on Drylands Pastoral Systems and Climate Change [47].

This new document concluded that good management can make farming one of the activities providing greater mitigation of greenhouse gases. However, this management requires a coordinated global effort to overcome the economic and socio-political barriers and facilitate both productivity and carbon sequestration in pastures around the globe [47].

In this environment, the need arises for a response from the beef production chain, through the initiative of sustainable farming.

This type of farming has been characterized in Europe [48] as one that involves protection and improvement of natural environment, animal welfare and the conditions of local communities while being productive and efficient.

In Brazil, the most advanced experience is organic farming ("organic beef"), which already has a certification seal. Animals are exclusively at pasture and treated with homeopathic and herbal products [22, 27].
The authors and agents believe that organic livestock farming is different from sustainable livestock farming ("green cow" or "natural beef") discussed in this article but recognize that both represent opportunities to demonstrate sustainability in beef cattle.

Livestock farming sustainability requires a balance with environmental laws, which has led to discussion among the agents within the chain. On one hand, there are obligations relating to the environment and law (legal reserve and productivity) and on the other hand, there is societal pressure regarding livestock in the areas of deforestation, greenhouse gas emissions and water consumption [49].

To contribute to the discussion characterizing sustainable farming within the Brazilian beef chain, a framework was elaborated from various documentary sources, gathering the perceptions and demands of consumers and non-governmental organizations (NGOs), understandings and results of research institutions, actions and directives of the government, and guidelines for producers, processors and distributors (Table 1).

The analysis of the results gathered in Table 1 refers to the second approach presented regarding market orientation, as breeders, processors and retailers must generate information (that today is published by NGOs) concerning the current and future needs of consumers of sustainable livestock in efforts to develop the abilities to fulfill these needs along with research and technology institutions. This strategy has already been used by international retailers operating in Brazil followed by boutique meats and breeders.

Examining the information from the perspective of demand chains, it is clear that certain opportunities to demonstrate sustainability in the beef cattle industry will focus on meeting the demand in certain markets. The objective in the DC is to generate revenue through consumer understanding and demand management. An example that could be mentioned is 
Table 1 Sustainability and agents of the beef chain in Brazil.

\begin{tabular}{|c|c|c|}
\hline Chain links & Agents & Action \\
\hline \multirow[b]{2}{*}{ Consumption } & \multirow[b]{2}{*}{$\begin{array}{l}\text { Consumers } \\
\text { NGOs }\end{array}$} & Perceptions/demands \\
\hline & & $\begin{array}{l}\text {-Concerned about consuming products from productive chains that adopt environmentally and socially } \\
\text { correct practices [45] } \\
\text {-I wish to "eat well, safe, and with a clean conscience" [50] } \\
\text {-Animal welfare and food security [27] } \\
\text {-Many consumers are taking part in groups about sustainable livestock [51] }\end{array}$ \\
\hline \multirow[b]{2}{*}{ Research } & \multirow[b]{2}{*}{$\begin{array}{l}\text { Research \& } \\
\text { technology } \\
\text { institutions }\end{array}$} & Understandings/results \\
\hline & & $\begin{array}{l}\text {-Development of environmental accounting methodologies that better portray Brazilian reality: ecological } \\
\text { footprint (ha per capita) and carbon footprint (greenhouse gas emissions: } \mathrm{kg} \mathrm{CO}_{2} \text {-e/kg product) [52] } \\
\text {-Vegetation cover and fragmentation } \\
\text {-Comparative studies of the economics of mitigation alternatives } \\
\text {-Research of more productive fodder varieties and farming/breeding integration [53] } \\
\text {-Invest in researching the carbon cycle in Brazilian soils and productive systems }\end{array}$ \\
\hline \multirow[b]{2}{*}{ Distribution } & \multirow[b]{2}{*}{ Retailers } & Orientations \\
\hline & & $\begin{array}{l}\text {-Suspend the purchase of meat from deforestation areas in the Amazon [54] } \\
\text {-Cattle Origin Guarantee Program [55] } \\
\text {-Comply with the "Cattle Breeding Pact" [56] } \\
\text {-Signature of specific term commitment [57] } \\
\text {-Creation of sustainable labels (certificates) } \\
\text {-Meat brands, with differentiation and added value [58] }\end{array}$ \\
\hline \multirow[b]{3}{*}{ Processing } & \multirow{3}{*}{$\begin{array}{l}\text { Beef } \\
\text { industry } \\
\text { Slaughter- } \\
\text { houses }\end{array}$} & Orientations \\
\hline & & $\begin{array}{l}\text { Program for the cattle purchase procedure [59] } \\
\text {-Investments in sustainability and incentives to sustainable livestock breeders } \\
\text {-Do not raise cattle or purchase meat from conservation areas (or brazilin native reserves) }\end{array}$ \\
\hline & & $\begin{array}{l}\text {-Observe the labor regulation from ministry of work and data from IBAMA [56] } \\
\text {-Reuse tannery waste as soil fertilizer } \\
\text {-In addition to competing with other countries for markets, there is also competition among national } \\
\text { and international chains [60] }\end{array}$ \\
\hline
\end{tabular}

Orientations

-Mitigation of greenhouse gases through: natural recovery/reform of degraded pastures, genetic improvement, feedlot and farming/breeding integration

-Increase in pasture capacity; increase in pasture biodiversity; improve soil fertility and permeability

Breeders conditions; reduction of residue levels; natural control of plagues and conservation of water resources

-Explore the Brazilian Development Bank (BNDES) funding lines in pasture recovery [61]

Production -Demystify livestock breeding as a villain in the environmental degradation process

-Education: diffusion of such concepts in schools [62]

-Sustainable Brahman Project and "Boi Guardião" Program [63]

-Carbon credit (often called a carbon offset) commercialization

Orientations

Suppliers $\quad$-Genetics for sustainable livestock breeding [64]

-Specific inputs for organic livestock breeding [27]

\section{Actions/guidelines}

-Allocate resources for environmental adequacy projects regarding livestock activities

-New Forest Code (undergoing the approval process)

-Brazilian System of Beef and Bufallo Meat Identification (SISBOV): Brazilian identification and

Regulation Government certification system of cattle and buffalo origins

-“Brazilian Beef”: highlight the natural pasture breeding system, efficacy of herds’ sanitary control programs and excellence of slaughterhouses

-Brazil's competitive advantages in sustainability: large availability of land, water and sunlight, cheap workforce, good supply of inputs, access to production technologies, privileged position in climatic diversity, adaptation of the zebu breed to the tropics and breeder vocation $[44,65]$

organic livestock. Additionally, depending on the case, the principle of demand chains can serve to guide supply actions and align business processes within and among actors, increasing the effectiveness of those already pursuing more sustainable livestock.

Having as principle the study of MO and DC 
theories, an understanding of the sustainability concept in agribusiness, the analysis of global livestock data in Brazil, and information from a documental survey about sustainable livestock breeding, it was found that the traditional beef chain's characteristics do not change in the short and medium term because beef is still considered a commodity.

Therefore, from the moment, Brazil became one of the world's largest producers and exporters, the pressure for sustainability-which was previously restricted to particular forms and alternatives of production-became an element of competitiveness. Thus, livestock sustainability lato sensu ("natural” cattle and "green" cattle) would today be a market orientation, whereas certain of its possibilities in stricto sensu ("organic" cattle) could form demand chains.

\section{Conclusions}

This paper aims to identify the sustainability state of the art in agribusiness and contribute to the discussion characterizing sustainable farming in Brazil and focusing on the beef chain.

The outline dimensions of sustainability in agriculture from the benchmark practices indicate that the requirements of environmental, technological and social order definitely entered the agenda of agribusiness organizations and is necessary to deepen the inter-dimensional joint in which various interests are being equated.

The livestock data confirm the importance of Brazil in the world scenario of beef production but indicate that the expansion has occurred in areas of environmental stress. This may mean production restrictions and particularly for the commercialization of beef produced in such areas, as it has caused external pressure and demand reaction for sustainability among the chain links.

The table of sustainability orientations organized from different documental sources demonstrates that consumers' and NGOs' perceptions and demands encompass the idea of producing and consuming with security, as well as social and environmental responsibility, even though this creates a cost to be equated with all segments; the results of research institutions note the development of environmental accounting methodologies that portray the Brazilian reality; government actions aim to regulate the expansion of and bestow credibility in the internal and external markets; orientations to breeders, processors, and distributors pervade reducing pasture degradation, mitigating greenhouse gas emissions and increasing productivity as the most important factors for advancing sustainability according to current understanding.

It was found that many of the technological guidelines for sustainable production were the same ones that might increase the producer's economic efficiency. It was observed that perceptions had converged among the chain agents, although they were not yet fully harmonized. In the Brazilian case, the increment of initiatives and dissemination of sustainable practices among the beef chain in the next years is recommended to provide a coordinated response of production, processing and distribution organizations facing market opportunities for sustainable livestock.

\section{Acknowledgments}

The authors are thankful to Brazilian Council for Scientific and Technological Development/Conselho Nacional de Desenvolvimento Científico e Tecnológico (CNPq), Universidade do Extremo Sul Catarinense (UNESC), Centro de Estudos e Pesquisas em Agronegócios (CEPAN) and Núcleo de Estudos em Sistemas de Produção de Bovinos de Corte e Cadeia Produtiva (NESPRO) from Universidade Federal do Rio Grande do Sul (UFRGS).

\section{References}

[1] J. Elkington, Towards the sustainable corporation: Win-win-win business strategies, for sustainable development, California Management Review 36 (2) 
(1994) 90-100.

[2] United Nations, United Nations General Assembly, World summit outcome: resolution A/60/1 [Online], New York, UN, Oct. 25, 2005, p. 38, http://unpan1.un.org/intradoc/groups/public/documents/u n/unpan021752.pdf (accessed May 22, 2012).

[3] W.M. Adams, The Future of Sustainability: Re-thinking Environment and Development in the Twenty-First Century, Report of the IUCN renowned thinkers meeting [Online], IUCN, Zurich, 2006, pp. 29-31, http://cmsdata.iucn.org/downloads/iucn_future_of_sustan ability.pdf (accessed May 20, 2012).

[4] SAI, Sustainable Agriculture Initiative Platform, Annual report [Online], 2010, http://www.saiplatform.org/library (accessed May 21, 2012).

[5] L.M.A. Bettencourt, J. Kaur, Evolution and structure of sustainability science, PNAS 108 (49) (2011) 19540-19545.

[6] J.C. Narver, S.F. Slater, The effects of a market orientation on business, Journal of Marketing 54 (4) (1990) 20-35.

[7] A.K. Kohli, B.J. Jaworski, Market orientation: The construct, research propositions and managerial implications, Journal of Marketing 54 (1990) 1-18.

[8] E.T. Micheels, H.R. Gow, Market orientation, innovation and entrepreneurship: An empirical examination of Illinois beef industry, International Food and Agribusiness Management Review 11 (3) (2008) 31-56.

[9] D. Dougherty, A practice-centered model of organizational renewal through product innovation, Strategic Management Journal 33 (1992) 77-92.

[10] C. Homburg, C. Pflesser, A multiple-layer model of market-oriented organizational culture: Measurement issues and performance outcomes, Journal of Marketing Research 37 (4) (2000) 449-462.

[11] B.J. Jaworski, A.K. Kohli, Market orientation: Antecedents and consequences, Journal of Marketing 57 (3) (1993) 53-70.

[12] S. Deng, J. Dart, Measuring market orientation: A multi-factor, multi-item approach, Journal of Marketing Management 10 (1994) 725-742.

[13] A.H. Kirca, S. Jayachandran, W. Bearden, Market orientation: A meta-analytic review and assessment of its antecedents and impact on performance, Journal of Marketing 69 (2) (2005) 24-41.

[14] V.A. Vieira, Antecedents and consequences of market orientation: A Brazilian meta-analysis and an international mega-analysis, Brazilian Administration Review 7 (1) (2010) 40-58.

[15] M.D. Canever, H.C.M. van Trijp, G. Beers, The emergent demand chain management: Key features and illustration from the beef business, Supply Chain Management: An
International Journal 13 (2) (2008) 104-115.

[16] J. Langabeer, J. Rose, Creating Demand Driven Supply Chains: How to Profit from Demand Chain Management, Spiro Press, London, 2002.

[17] T.E. Vollmann, C. Cordon, J. Heikkila, Teaching supply chain management to business executives, Production and Operations Management 9 (1) (2000) 81-90.

[18] S. de Treville, R.D. Shapiro, A. Hameri, From supply chain to demand chain: The role of lead time reduction in improving demand chain performance, Journal of Operations Management 21 (2004) 613-627.

[19] Master-plan of Embrapa: 2008-2011-2023 [Online], Strategic and Management Bureau, Brasília, 2008, p. 44, http://www.cnpt.embrapa.br/aunidade/PDE_V20081230_ CIMP.pdf (accessed June 18, 2012).

[20] S. Giordano, Marketing and environment, in: M.F. Neves, L.T. Castro (Eds.), Marketing and Strategy in Agribusiness and Development, Atlas, São Paulo, 2003. (in Portuguese)

[21] M.F. Neves, M.A. Conejero, Sociocultural scenario and the production of food, fiber and bioenergy, in: M.F. Neves (Ed.), Agribusiness and Sustainable Development: An Agenda for Global Leadership in Food Production and Bioenergy, Atlas, São Paulo, 2009, pp. 20-24. (in Portuguese)

[22] S.A. Santos, E.L. Cardoso, R.A.M.S. Silva, A.O. Pellegrin, Basic Principles for Sustainable Production of Beef Cattle in the Pantanal [Online], Embrapa Pantanal, Corumbá, Brazil, 2002, http://www.cpap.embrapa.br/publicacoes/online/DOC37. pdf (accessed May 20, 2012).

[23] Brazilian Institute of Geography and Statistic (IBGE), Agriculture Census 2006: Preliminary Results, Rio de Janeiro, 2006. (in Portuguese)

[24] Liverstock, Cattle Selected Countries Summary, Production, supply and distribution online reports, United States Department of Agriculture, Washington, 2009.

[25] ANUALPEC 2010: Brazilian Livestock Yearbook, FNP, São Paulo, 2010. (in Portuguese)

[26] K.J. Calker, P.B.M. Berentsen, G.W.J. Giesen, R.B.M. Huirne, Identifying and ranking attributes that determine sustainability in Dutch dairy farming, Agriculture and Human Values 22 (1) (2005) 53-63.

[27] I.T. Domingos, Beef cattle sustainability: Niche-market and access to markets in the vision of WWF Brasil, in: Proceedings of Sustainable Livestock Beefpoint Workshop [Online], WWF, São Paulo, 2009, http://www.beefpoint.com.br/cadeiaprodutiva/sustentabili dade/pecuaria-sustentavel-nicho-de-mercado-e-acesso-amercados-na-visao-do-wwf-video-slides-e-artigo-58163 (accessed May 23, 2012).

[28] G.H. Brundtland, Our Common Future: The World 
Commission on Environment and Development [Online], Oxford University Press, Oxford, 1987, http://www.vliz.be/projects/indicatoren/fiches/brundtland LQ.pdf (accessed May 23, 2012).

[29] J.W. Hansen, Is agricultural sustainability a useful concept?, Agricultural Systems 50 (1996) 117-143.

[30] FACTA, Food, Agriculture, Conservation and Trade Act of 1990: Public Law 101-624, Title XVI, Subtitle A, Section 1603, Government Printing Office, Washington, 1990.

[31] J. Nill, R. Kemp, Evolutionary approaches for sustainable innovation policies: From niche to paradigm?, Research Policy [Online], 38 (4) (2009) 668-680, http://dx.doi.org/10.1016/j.respol.2009.01.011 (accessed June 19, 2012) .

[32] D.W. Brinkerhof, A.A. Goldsmith, Promoting the sustainability of development institutions: A framework for strategy, World Development 20 (3) (1992) 369-383.

[33] J. Hawkes, The Fourth Pillar of Sustainability: Culture's Essential Role in Public Planning, Common Ground Publishing, Melbourne, 2001.

[34] I. Sachs, Paths to Sustainable Development, Garamond, Rio de Janeiro, 2002. (in Portuguese)

[35] H. Hadders, The adaptive quadruple bottom line scorecard: Measuring organizational sustainability performance [Online], University of Groningen, 2009, http://www.csin-rcid.ca/downloads/csin_conf_henk_hadd ers.pdf (accessed June 23, 2012).

[36] V. Veleva, M. Hart, T. Greiner, C. Crumbley, Indicators of sustainable production, Journal of Cleaner Production 9 (5) (2001) 452-477.

[37] E. Manzini, C. Vezzoli, Development of Sustainable Products: Environmental Requirements of Industrial Products, EdUSP, São Paulo, 2002. (in Portuguese)

[38] E. Batista, R. Cavalcanti, M.A. Fujihara, Sustainable Drive in Brazil, Art World, São Paulo, 2005. (in Portuguese)

[39] H.M.S. Filho, Sustainable agricultural development, in: M.O. Batalha (Ed.), Agroindustrial Management, 3rd ed., Atlas, São Paulo, 2009, pp. 665-710. (in Portuguese)

[40] J.O.J. Barcellos, Y.B.P. Suñé, L.F. Christofari, C.E.N. Semmelmann, F.S. Brandão, Beef cattle in Brazil: A systemic approach from production to product differentiation, Journey of Comparative Regional Economy [Online], Porto Alegre, 2005, http://www.fee.rs.gov.br/sitefee/download/jornadas/2/e13 -03.pdf (accessed June 19, 2012).

[41] G. Fortes, F. Yassu, Brazilian Beef Cattle Miracle, Publique, São Paulo, 2009. (in Portuguese)

[42] G.C. Malafaia, J.O.J. Barcellos, E.A. Pedroso, Livestock farming and local agri-food system: Scene from Brazil, Journal of Indian Management 5 (2008) 80-91.
[43] D. Veronez, The conflict between sustainable livestock and forestry code, in: Proceedings of Workshop on Sustainable Livestock Beef Point Workshop, São Paulo, 2009. (in Portuguese)

[44] T.B. Carvalho, S. de Zen, Characterization of livestock raising activity in Pantanal, Amazônico Cerrado biomes, in: Proceedings of Brazilian Society of Administration, Economics and Rural Sociology Congress, UCDB, Campo Grande, 2010. (in Portuguese)

[45] A.M. Buainain, M.O. Batalha, Beef Cattle Chain [Online], IICA, MAPA, SPA, Brasília, 2007, http://www.iica.org.br/Docs/CadeiasProdutivas/Cadeia\% 20Produtiva\%20da\%20Carne\%20Bovina\%20c\%20capa. pdf. (in Portuguese)

[46] H. Steinfeld, P. Gerber, T. Wassenaar, V. Castel, M. Rosales, C. Haan, Livestock's long shadow: Environmental issues and options [Online], Roma, 2006, http://virtualcentre.org/en/library/key_pub/longshad/A07 01E 00.pdf (accessed May 23, 2012).

[47] C. Neely, S. Bunning, A. Wilkes, Review of Evidence on Drylands Pastoral Systems and Climate Change: Implications and Opportunities for Mitigation and Adaptation, Food and Agriculture Organization of the United Nations, Rome, 2009.

[48] K.J. Calker, P.B.M. Berentsen, G.W.J. Giesen, R.B.M. Huirne, Identifying and ranking attributes that determine sustainability in Dutch dairy farming, Agriculture and Human Values 22 (1) (2005) 53-63.

[49] L.C. Canellas, P.R. Marques, V.N. Lampert, J.O.J. Barcellos, Livestock in Southern Brazil: Context of Opportunities [Online], Anuário, Bagé, 2009, pp. 124-133, http://www.ufrgs.br/nespro/sysdownloads/arqu ivos/outros/Texto_Anuario_Hereford.pdf (accessed June 6, 2012).

[50] J.Y. Carfantan, Livestock sustainability: A priority in global retail, in: Proceedings of Sustainable Livestock Congress 2010, APPS, São Paulo, 2010. (in Portuguese)

[51] International Finance Corporation, World Bank Group Issue Brief Brazil Amazon Initiative [Online], 2008, http://www.ifc.org/ifcext/media.nsf/AttachmentsByTitle/ AM08_Brazil_Amazon/\$FILE/AM08_Brazil_Amazon_I nitiative_IssueBrief.pdf (accessed June 18, 2012).

[52] C.C. Cerri, J.L. Carvalho, Brazilian livestock greenhouse gas emissions assessment, in: Proceedings of Sustainable Livestock Congress, APPS, São Paulo, 2010. (in Portuguese)

[53] J. Melado, Voisin Rational Grazing: Fundamentals-Applications-Projects, Learn Easy, Viçosa, 2003. (in Portuguese)

[54] Pão de Açucar Group, Sustainable Products [Online], http://www.grupopaodeacucar.com.br/responsabilidade-s 
ocioambiental/ambiental/iniciativas-5.htm (accessed June 20, 2012).

[55] Carrefour Group, Carrefour launches new private brand beef [Online], 2011, http://www.grupocarrefour.com.br/ imprensa/releases/carrefour-lanca-carne-nova-de-marca-p ropria (accessed June 21, 2012).

[56] PACTO da pecuária, Proceedings of Sustainable Connections Seminar [Online], Sustainable Amazon Forum, São Paulo, 2008, http://www.ethos.org.br/ sistemas/conexoessustentaveis/pecuaria/pacto.asp (accessed June 20, 2012).

[57] Walmart Group, Top Sustainable Products [Online], 2011, http://www.walmartsustentabilidade.com.br/produtos-sust entaveis (accessed June 21, 2012).

[58] M.R. Cavalcanti, The search for a meat chain value [Online], São Paulo, 2004, http://www.beefpoint.com.br (accessed June 20, 2013).

[59] JBS Group, Sustainable Livestock Report [Online], 2011, http://www.jbs.com.br/PecuariaSustentavel.aspx (accessed June 19, 2013).

[60] M.S.B.L. Saab, M.F. Neves, L.G. Claudio, The challenge of coordination and its impact on the competitiveness of chains and agribusiness systems, Brazilian Journal of Animal Science 38 (2009) 412-422. (in Portuguese)

[61] R. Paniago, A sustainable way for cattle breeding in Brazil, Rural Cattle Breeder Magazine 5 (2009) 50-51. (in Portuguese)

[62] Professionals' Association for Sustainable Livestock [Online], São Paulo, 2010, http://www.pecuariasustentavel.org.br (accessed Apr. 13, 2012).

[63] S. Nascimento, Has Ox in the Forest, Rural Globe, São Paulo, 2010, pp. 14-25. (in Portuguese)

[64] R. Rodrigues, Seminar highlights genetics to sustainable livestock [Online], 2010, http://www.agrosoft.org.br/ agropag/213577.htm (accessed May 12, 2012).

[65] N.R. Pineda, J.C.M.C. Rocha, Marketing strategies and marketing alliances in the beef production chain, in: Proceedings of Beef Cattle Production Symposium SIMCORTE [Online], Viçosa, 2002, http://simcorte.com/index/Plestras/t_simcorte/01_pineda_ PDF (accessed June 24, 2013). 